\title{
The Urgency to Incorporate the Islamic Concept of Rights into the International Human Rights Law Course in Indonesian Law Schools
}

\author{
Sigit Riyanto \\ Department of International Law and Dean of the Faculty of Law, \\ Universitas Gadjah Mada, Jl. Sosio-Yustisia No. 1, Bulaksumur, Yogyakarta \\ Email: riyanto@gadjahmada.edu \\ Fajri Matahati Muhammadin \\ Department of International Law, Faculty of Law, \\ Universitas Gadjah Mada, Jl. Sosio-Yustisia No. 1, Bulaksumur, Yogyakarta
}

Article history: Received: 25 February 2019, Accepted: 6 October 2019,

Published: 11 July, 2019

\begin{abstract}
:
The discourse between International Human Rights Law (IHRL) and Islam has been a longstanding one. However, not all IHRL courses in Indonesia include Islamic human rights as one of the taught chapters. This normative research explores the urgency to include Islamic human rights in the IHRL curriculum and finds that it is indeed urgent to do so. There are two reasons found to include Islamic human rights in IHRL. First, it is a counter to the Eurocentric discourse of IHRL. Second, there are paradigmatic differences between IHRL and Islam which, if not understood, will make it difficult to fairly consider the discourse and analyze the derivative issues. There are two paradigmatic differences between IHRL and Islamic human rights, which are the epistemology and rights-obligation construction.
\end{abstract}

Keywords:

Islam; Human Rights Law; International Law; Indonesian.

Author correspondence email: riyanto@gadjahmada.edu Available online at: http:/ / ejournal.iainmadura.ac.id/index.php/alihkam/ Copyright (c) 2019 by al-ihkam. All Right Reserved 
The Urgency to Incorporate the Islamic Concept of Rights

\begin{abstract}
Abstrak:
Diskursus antara Hukum Hak Asasi Manusia Internasional (HHAMI) dan Islam telah ada sejak lama dan hingga kini tidak habis-habis. Akan tetapi, ternyata tidak semua mata kuliah HHAMI yang diajarkan di fakultas-fakultas hukum Indonesia memasukkan HAM Islam sebagai salah satu pokok bahasan. Penelitian yang bersifat normatif ini akan mengkaji urgensi memasukkan konsep HAM Islam ke dalam kurikulum HHAMI di mana hal tersebut diketahui memiliki urgensi. Ditemukan dua alasan utama untuk melakukan hal tersebut. Pertama, sebagai salah satu counter terhadap narasi Eurosentrisme dalam diskursus HHAMI. Kedua, ternyata ada beberapa perbedaan yang bersifat paradigmatik antara HHAMI dan Islam, yang apabila tidak dikenal maka akan sulit mendudukkan diskursus HHAMI dan Islam dengan akurat apalagi mengkaji isu-isu turunan dengan tepat. Perbedaan paradigmatik ini ada dua, yaitu pada tatanan epistemologi serta konstruksi antara hak dan kewajiban.
\end{abstract}

Kata Kunci:

Islam; Hak Asasi Manusia; Hukum Internasional; Indonesia.

\title{
Introduction
}

There are so many discourses between international human rights law (hereinafter, IHRL) and Islam. So many fierce debates occur on this issue, and perhaps it can be agreed by all that there are matters of agreement and disagreements between IHRL and Islam. ${ }^{1}$ The differences are not only in the detailed rights and application, but also at a paradigmatic level as this research will show. ${ }^{2}$ Therefore, it

\footnotetext{
${ }^{1}$ See inter alia: Abdullahi Ahmed An-Na'im, "Why Should Muslims Abandon Jihad? Human Rights and the Future of International Law," Third World Quarterly 27, No. 5 (2006): 785-97; Mashood A. Baderin, Hukum Internasional Hak Asasi Manusia dan Hukum Islam (Jakarta: Komisi Nasional Hak Asasi Manusia, 2010); Ann Elizabeth Mayer, "Universal versus Islamic Human Rights: A Clash of Cultures or Clash with a Construct," Mich. J. Int'l L. 15 (1993): 307.

2 The differences can go as deep as epistemology, as Islam and the Western-secular rooted human rights concept are worlds apart in this regard. Surely the derivative products (knowledge and rules) of the two would have differences that cannot be comprehended without first understanding the paradigmatic differences. This research goes deeper into this. Further reading on this difference of epistemology:
} 
should be common sense to teach the Islamic concept of rights as one of the subjects in the teaching of IHRL in the world, and it should be more so in Islamic nations. ${ }^{3}$

However, a short survey conducted by the Research Team reveals that the teaching of IHRL courses in several universities in Indonesia has little to do with Islamic rights content. How can a law graduate understand, interpret, and apply Islamic laws or laws influenced by Islamic teachings without understanding or even knowing Islamic law theories? This is despite Islam being the secondlargest religion in the world, ${ }^{4}$ and Indonesia has the largest Muslim population in the world. ${ }^{5}$ Besides, the Indonesian legal system has some Islamic influence albeit not formally being an Islamic state. The making of the Pancasila as the state ideology and 'source of all sources of law' was very heavily influenced by Islamic teachings and the Muslims. ${ }^{6}$

Some researches have addressed concern towards the issue mentioned above and also suggested prospects towards Islamization of knowledge. ${ }^{7}$ Those researches focus only on the Introduction to Jurisprudence course and only on particular chapters. As for the relation between IHRL and Islam, academic works mostly discuss the prospect of reconciliation the two different. ${ }^{8}$ It is difficult to find researches addressing the urgency to apply Islamization of

Adian Husaini and Dinar Dewi Kania, eds., Filsafat Ilmu: Perspektif Barat dan Islam (Jakarta: Gema Insani Press, 2013).

${ }^{3}$ See for example, at the Ahmad Ibrahim Kuliyyah of Laws, International Islamic University of Malaysia, there is a course named "Fundamental Rights in Islam".

${ }^{4}$ Drew Desilver and David Masci, “World's Muslim Population More Widespread than You Might Think," Pew Research Center, 2017, http://www.pewresearch.org/fact-tank/2017/01/31/worlds-muslim-populationmore-widespread-than-you-might-think/.

${ }^{5}$ Desilver and Masci.

${ }^{6}$ M. Saifullah Rohman, “Kandungan Nilai-Nilai Syariat Islam alam Pancasila," Jurnal Studi Agama Millah 13, No. 1 (2013): 209-11.

7 See inter alia: Fajri Matahati Muhammadin and Hanindito Danusatya, "DeSecularizing Legal Education in Indonesian Non-Islamic Law Schools: Examining The 'Introduction to Jurisprudence' Textbooks On The 'Norm Classification' Chapter," Ulul Albab: Jurnal Studi dan Penelitian Hukum Islam 1, No. 2 (2018): 135-58.

8 See inter alia: Mashood A Baderin, International Human Rights and Islamic Law (Oxford: Oxford University Press, 2003). Baderin's work juxtaposes the rights in IHRL and Islam and suggests possible ways to reconcile the differences. 
knowledge specifically in the context of the teaching of IHRL. Therefore, this research brings forth something new by observing the need for Islamization of knowledge in the context of teaching IHRL.

This research observes the urgency to incorporate the Islamic concept of rights into the IHRL courses in law schools. There are two major problems found, and it is these two problems which are discussed in this research: First, Islam's relation with international law throughout the ages has been met with problems of 'Eurocentrism'. Second, there are two paradigmatic differences between IHRL and the Islamic concept of rights, which are: Epistemology (secular and nonsecular), and the construct of rights and responsibilities. These two problems are the focus of the discussion in this research, and it is found that they are essential to understand to objectively comprehend the discourse of IHRL and Islam. Likewise, it will be very difficult to understand the discourse of IHRL and Islam without introducing the Islamic concept of rights, especially at the paradigmatic level, in the IHRL courses.

\section{Method}

This research is mainly doctrinal legal research that analyses legal principles, doctrines, and theories and their relevance towards the teaching of IHRL. Two approaches will be combined, i.e. postcolonial theories in critical international law especially as argued by Antony Anghie, and the Islamic worldview as developed by Syed Muhammad Naquib Al-Attas. A literature review is conducted primarily using information and data obtained from books, articles, researches, and the primary, secondary, and tertiary sources of law of both international and Islamic law.

\section{Discussion and Result}

Unlike the secular understanding of what 'religion' means and encompasses, Islam is an Al-dîn whose meaning includes 'judicious power'. ${ }^{9}$ The Islamic legal system itself has the Al-Qur'ān and Sunnah

\footnotetext{
9 Edward William Lane, An Arabic-English Lexicon: In Eight Parts, Vol. 3 (Bayrūt: Librairie du Liban, 1968), 942-47. For a detailed comparison between the Islamic notion of 'religion' and the secular one, see Syed Muhammad Naquib Al-Attas, Islam and Secularism (Kuala Lumpur: ISTAC, 1993); Zara Khan, "Refractions Through the
} 
as primary sources, and matters not specifically and explicitly regulated in those primary sources will be derived from those primary sources through ijtihâd. ${ }^{10}$

\section{Islam and International Law}

One of the branches of Islamic law (figh) regulates the conduct of the Islamic nation with other nations, namely figh al-siyar (known also as the 'Islamic international law').11 This branch of figh recognizes agreements and customary laws as source of law as long as they do not contradict the primary sources. ${ }^{12}$ Figh al-siyar has historically contributed positively to the development of the norms of international law. ${ }^{13}$ There are claims that the first charter of rights in the world is the Madinah Charter. ${ }^{14}$ In this age, there is still a little role for Islamic law in modern international law, such as the use of Islamic law rules or maxims by the judges of the International Court of Justice. ${ }^{15}$

Additionally, there are numerous human rights treaties ratified by Muslim nations that also submitted reservations based on Islamic law. ${ }^{16}$ The practice of these Islamic nations which diverges from the

Secular: Islam, Human Rights, and Universality" (The City University of New York, 2016).

${ }^{10}$ Imran Ahsan Khan Nyazee, Islamic Jurisprudence (Selangor: The Other Press, 2003), 20; Wahbah al-Zuhaylī, Ușūl Al-Fiqh Al-Islāmī, vol. 1 (Tehran: Dar Ihsan, 1997), 19; 'Abd al-Karim Zaydan, Synopsis on the Elucidation of Legal Maxims in Islamic Law, trans. Md. Habibur Rahman and Azman Ismail (Kuala Lumpur: IBFIM, 2015), 29.

${ }^{11}$ Imam Al-Shaybānī, The Islamic Law of Nations: Shaybani's Siyar, trans. Majid Khadduri (Maryland: John Hopkins Press, 1966), 5-6.

${ }^{12}$ Al-Shaybānī, 8.

${ }^{13}$ Jean Pictet, Development and Principles of International Humanitarian Law (Geneva: Henry Dunant Institute, 1985), 15-17; Nahed Samour, “Is There a Role for Islamic International Law in the History of International Law?," European Journal of International Law 25, no. 1 (2014): 313-19.

${ }^{14}$ Badria Al-Awadhi, "Address by the Dean of the Faculty of Law and Shari'a in the University of Kuwait," in Human Rights in Islam (Geneva: International Commission of Jurists, 1982), 28.

${ }^{15}$ Awn S. Al-Khasawneh, "Islam and International Law," in Islam and International Law: Engaging Self-Centrism from a Plurality of Perspectives, ed. Marie-Luisa Frick and Andreas Th Müller (Martinus Nijhoff Publishers, 2013), 34-41.

${ }^{16}$ Such as the International Covenant on Civil and Political Rights 1966 (ICCPR_ and Convention on the Elimination of all Forms of Discrimination Against Women 1979 (CEDAW), where many Islamic states made reservation. 
other nations may be recognized as a persistent objection that creates an exception from the development of the customary international law ${ }^{17}$ of human rights. This is in addition to the Cairo Declaration on Human Rights in Islam (1990). However, there are various challenges and problems which diminish the role of Islam in international law. Some scholars suggest that it is partly due to the failure of the Organization of Islamic Cooperation to take lead, 18 while others point their fingers towards the crisis of knowledge within the Islamic community itself. ${ }^{19}$

\section{'Eurocentrism' as an External Problem}

Scholars do not seem to deny that modern international law is of European origin. Some of these scholars accept this without questioning further, ${ }^{20}$ but other scholars and thinkers, especially those using the post-colonial theory, are more critical and point out that there has been an injustice throughout history which needs to be corrected.

These thinkers have traced back this problem to medieval Europe during the rise of the natural law school of Fransisco De Vitoria who justified colonialism as the center of international law at the time: The 'civilized nations' (i.e. the European nations) must 'civilize the uncivilized nations' (i.e. other than the European nations). ${ }^{21}$

\footnotetext{
${ }^{17}$ Malcolm N Shaw, International Law, 6th ed. (New York: Cambridge University Press, 2008), 91-93. There is a debate on the 'other states' approval' requirement in this.

18 See inter alia: Salim Farrar, "The Organisation of Islamic Cooperation: Forever on the Periphery of Public International Law?," Chinese Journal of International Law 13, no. 4 (2014): 787-817.

19 See inter alia: Syed Muhammad Naquib Al-Attas, Risalah untuk Kaum Muslimin (Kuala Lumpur: ISTAC, 2001).

20 Sugeng Istanto, Hukum Internasional (Yogyakarta: Penerbit Universitas Atmajaya Yogyakarta, 1994), 9-10.

${ }^{21}$ Antony Anghie, Imperialism, Sovereignty, and the Making of International Law (New York: Cambridge University Press, 2004), 251. This train of thought was adopted by other scholars in that era including those dubbed as 'fathers of international law' such as Emer de Vattel. De Vattel justified the conquest over the natives of North America because these natives were nomadic, while the 'natural law' (according to the Europeans, that is) demands the permanent cultivation of the lands. See Emer De Vattel and Joseph Chitty, The Law of Nations: Or, Principles of the Law of Nature, Applied to the Conduct and Affairs of Nations and Sovereigns (PH Nicklin \& T. Johnson, 1835), 35.
} 
In that global colonial era, the colonial powers have made various efforts to eradicate the practice of Islamic law in their colonies. For example, in the part of Nusantara (which is now Indonesia), wellestablished and pre-existing adat and Islamic courts were abolished and replaced by the Dutch law courts.22 It was only after independence that Islam could become an important element in the system of governance in Indonesia, ${ }^{23}$ and this is even only to a few matters. This was how a 'Eurocentric' international law was formed, and then preserved through the era of legal positivism. ${ }^{24}$ It was even further preserved throughout the post-World War II decolonization period, ${ }^{25}$ and continues to this day where the European (more referred to as 'Western') worldview becomes the measure of truth and correctness by the mere virtue of being Western. ${ }^{26}$

Examples of this include the imposition of the Western human rights standards of good governance at the World Bank, ${ }^{27}$ strange and ill-justified UN reports issued by the Committee Against Torture and UN Rapporteurs regarding lashing as a penalty, 28 the European Union policy on investments which requires the investee state to apply EU-

\footnotetext{
${ }^{22}$ Ramlah, "Implikasi Pengaruh Politik Hukum Kolonial Belanda Terhadap Badan Peradilan Agama di Indonesia," Jurnal Kajian Hukum Islam 12, No. 1 (2012): 386-90.

${ }^{23}$ As explained earlier, even the Pancasila as state ideology was heavily influenced by Islam and the Muslims. See: Rohman, "Kandungan Nilai-Nilai Syariat Islam dalam Pancasila"; Marybeth T. Acac, "Pancasila: A Contemporary Application of Maqasid Al-Shari'Ah?," Journal of Indonesian Islam 9, no. 1 (2015): 59-78.

${ }^{24}$ Fajri Matahati Muhammadin, "Universalitas Hak Asasi Manusia dalam Hukum Internasional: Sebuah Pendekatan Post-Kolonial," in Hak Asasi Manusia: Dialektika Universalisme vs Relativisme Di Indonesia, ed. Al-Khanif, Herlambang P. Wiratraman, and Manunggal Kusuma Wardaya (Yogyakarta: LKiS, 2017), 7; John Austin, The Province of Jurisprudence Determined (London: John Murray, 1832), 1-2.

${ }^{25}$ Anghie, Imperialism, Sovereignty, and the Making of International Law, 254; Antony Anghie, "Towards a Postcolonial International Law," in Critical International Law: Post-Realism, Post Colonialism, and Transnationalism, ed. Prabakhar Singh and Benoit Mayer (Oxford-New Dheli, 2014), 136-37.

${ }^{26}$ Wan Mohd Nor Wan Daud, Islamization of Contemporary Knowledge and the Role of the University in the Context of De-Westernization and Decolonialization (Johor Baru: UTM Press, 2013), 6-7.

27 The primary victims were the Latin American States. See Anghie, Imperialism, Sovereignty, and the Making of International Law, 261-62.

${ }^{28}$ Fajri Matahati Muhammadin et al., "Lashing in Qanun Aceh and the Convention Against Torture," Malaysian Journal of Syariah and Law 7, no. 1 (2019): 18-20.
} 
style human rights as prerequisite to investments, ${ }^{29}$ the imposition of the Western-secular gender equality standards in CEDAW, ${ }^{30}$ and many others. This is the unjust imposition of Western worldview and its products as a universal standard, 31 also referred to as 'Eurocentrism'.

\section{Traces of Eurocentrism in Law School Education}

It has been explained earlier how Islamic law in Indonesia has been heavily reduced due to colonialism. This heavily impacts education. For many years and decades, Islamic law is made alien to law students (including the Muslim students) except for the few parts of it already codified to the Indonesian national legislation. A survey has been conducted towards the law students (Muslims only) of one of the best law schools in Indonesia, and one hundred percent of the respondents did not know any basic of al-qawä'id al-fiqhiyyah, but they all recognized the Latin legal maxims which have the same meaning with the basic al-qawa' id al-fighiyyah asked to them. ${ }^{32}$

From the most fundamental aspects, the concept of religion as a norm is taught to display as if it is disconnected from other aspects of life. In the Introduction to Jurisprudence course, for example, most textbooks explain that 'religious norms' is a separate norm from the others such as legal norms, ethical/moral norms, and social norms (although they may complement each other). ${ }^{33}$ Religious norms are said to be: (i) only regulating human-God relations, and (ii) has

\footnotetext{
${ }^{29}$ Lorand Bartels, “The European Parliament's Role concerning Human Rights in Trade and Investment Agreements," 2014, http://www.europarl.europa.eu/cmsdata/86031/Study.pdf.

30 Muhammadin, "Universalitas Hak Asasi Manusia dalam Hukum Internasional: Sebuah Pendekatan Post-Kolonial," 12, 13, dan 16.

31 Padahal ia sejatinya tidaklah universal. Lihat: Muhammadin, "Universalitas Hak Asasi Manusia Dalam Hukum Internasional: Sebuah Pendekatan Post-Kolonial.”

32 Vina Berliana Kimberly, Novita Dwi Lestari, and Fajri Matahati Muhammadin, "Incorporating Qawaidh Fiqhiyyah to the 'Principles of Law' Chapter in the Introduction to Jurisprudence Course in Indonesia's Legal Education," in International Conference on Research in Islamic Education 2018 Conference Proceeding, Fakulti Tamadun Islam, Universiti Teknologi Malaysia (Kuala Lumpur: Springer, 2019), (upcoming).

${ }^{33}$ Sudikno Mertokusumo, Mengenal Hukum (Suatu Pengantar), 3rd ed. (Yogyakarta: Liberty, 1991), 5-12; Peter Mahmud Marzuki, Pengantar Ilmu Hukum (Jakarta: Prenadamedia Group, 2008), 79-83; Satjipto Rahardjo, Ilmu Hukum (Bandung: Citra Aditya Bhakti, 1991), 26.
} 
weaknesses because it only prescribes obligations and does not have worldly sanctions. ${ }^{34}$ On the other hand, Islam, as explained earlier, is not at all like that. ${ }^{35}$

Because of that, all courses with traces of Eurocentrism, including IHRL, must be critically reviewed and renewed. Otherwise, these courses will do nothing but preserve and continue the intellectual legacies of colonialism. It must be noted that the Preamble of the Indonesian constitution, in its first line, reads "...penjajahan di atas dunia harus dihapuskan." 36 Law students must be aware of a broader extent of the IHRL discourses. Particularly in the discussion of this research, the Islamic concept of rights must be introduced as it is not only a very contemporary discourse but also because it is very close to the identity of the Indonesian people which was once eroded by colonialism.

\section{Islam, Islamic Epistemology, and Its Implications}

An undeniable reality of the human rights concept in international law (i.e. IHRL) is its origin from a secular concept. ${ }^{37}$ This is despite some non-secular states that ratify the IHRL instruments and therefore implement them in a non-secular manner (insofar as they can do so).38 The problem is that the distinction between a secular and non-secular worldview is often understood only at the surface. This is while the differences between the two are very fundamental, and the failure to understand it would render students unable to properly and objectively understand derivative issues.

The first thing to understand is that the term 'secular' is fundamentally a worldview of reality as explained by C. A. van Peursen: "...deliverance first from religious, and then from metaphysical,

\footnotetext{
${ }^{34}$ Mertokusumo, Mengenal Hukum (Suatu Pengantar), 9-10.

35 See further: Muhammadin and Danusatya, "De-Secularizing Legal Education in Indonesian Non-Islamic Law Schools: Examining The 'Introduction to Jurisprudence' Textbooks on The 'Norm Classification' Chapter"; Khan, "Refractions Through the Secular: Islam, Human Rights, and Universality."

${ }^{36}$ Loosely translated: "... colonialism must be eradicated from the face of the earth."

${ }^{37}$ Michael Freeman, "The Problem of Secularism in Human Rights Theory," Human Rights Quarterly 26, no. 2 (2004): 399.

${ }^{38}$ For example Indonesia, Saudi Arabia, and others.
} 
control over human reason and language." 39 Secularism is then derived into the disenchantment of nature, the desacralization of politics, and deconsecration of values. 40

Secularism then affects epistemology, especially on the sources of knowledge. The human mind's ratio becomes the only criteria of truth and source of knowledge, ${ }^{41}$ while metaphysical realities have neither relevance nor epistemological value.42 One of the effects is the promulgation of secular-derived theories such as August Comte's Law of Three Stages which assumes that a man taking knowledge from religion is the most primordial stage of man, while a man taking knowledge from the scientific inquiry is the modern (and most advanced) man..$^{3}$

On the other hand, Islam is very different. The first time the AlQur'ān mentions taqwā, it is in the form of muttaqin ('people of taqwa $\left.\bar{a}^{\prime}\right) .{ }^{44}$ That mention is followed by a list of characteristics of the muttaqin, and the very first characteristic is 'to believe in the ghayb or unseen' ${ }^{45}$ How can someone believe in metaphysical realities without making them a source of knowledge? This is why the Islamic epistemology puts khabar sädiq or true news (which includes divine revelation) as one of the causes of knowledge other than ratio, senses, and intuition. ${ }^{46}$ This is where the secular and Islamic epistemology clash.

\footnotetext{
${ }^{39}$ Cited in: Harvey Cox, The Secular City: Secularization and Urbanization in Theological Perspective (New Jersey: Princeton University Press, 2013), 2.

${ }^{40} \mathrm{Al}-\mathrm{Attas}$, Islam and Secularism, 18.

${ }^{41}$ Adnin Armas and Dinar Dewi Kania, "Sekulerisasi Ilmu," in Filsafat Ilmu: Perspektif Barat dan Islam, ed. Adian Husaini and Dinar Dewi Kania (Jakarta: Gema Insani Press, 2013), 7.

${ }^{42}$ Justus Harnack, Kant's Theory of Knowledge (London: Macmillan Publisher, 1968), 142-45.

${ }^{43}$ Auguste Comte, "Plan of the Scientific Work Necessary for the Reorganisation of Society," in Comte: Early Political Writings, ed. H.S. Jones (Cambridge: Cambridge University Press, 1998), 81.

${ }^{44}$ Taqwā means the consciousness of Allah.

${ }^{45}$ Ghayb means 'the unseen', referring to things that exist in a metaphysical but not a physical materialistic plane. See Q.S al-Baqarah $2: 2-3$, especially verse 3 where the characteristics of the 'people of $t a q w \bar{a}$ ' are mentioned.

46 Sa'd al-Din Al-Taftazani, A Commentary on the Creed of Islam (Sa'd Al-Din AlTaftazani on the Creed of Najm Al-Din Al-Nasafi) (New York: Columbia University Press, 1950), 15-17.
} 
Some scholars such as Helen Quane merely demand that secular international law must take precedence over religious teachings when they contradict each other. ${ }^{47}$ Meanwhile, one cannot simply put manmade laws over God-made laws unless they have by default applied a secular framework that sees anything 'religious' as primordial as per Comte's theory. Quane simply dismisses the Islamic epistemology without any mention of it and bases her entire case on a secular view.

On the other hand, putting Islamic laws below other laws is one of the nullifiers of Islam. ${ }^{48}$ Even the Pancasila, considering what the First sila says, cannot accept Quane's argument. However, it may seem that Quane's position represents mainstream scholarship. Therefore, secular thinkers would not recognize the epistemological problem behind this train of thought and therefore unable to address the issue objectively and correctly.

\section{Case Study: Religious Blasphemy}

One of the most concrete case studies to best illustrate the significant difference between both epistemologies is the criminalization of religious blasphemy. On one hand, the position of IHRL is clear. Various bodies under the UN have stated that the criminalization of religious blasphemy is a violation of the freedom of expression. ${ }^{49}$ On the other hand, Islam supports the criminalization of religious blasphemy. There is a consensus among the classical Muslim jurists that religious blasphemy is punishable by death. ${ }^{50}$ Behind both of these different positions are significant epistemological differences.

\footnotetext{
${ }^{47}$ Helen Quane, "Legal Pluralism and International Human Rights Law: Inherently Incompatible, Mutually Reinforcing or Something in Between?," Oxford Journal of Legal Studies 33, No. 4 (2013): 675.

${ }^{48}$ Committing a nullifier of Islam would render a Muslim no longer within the fold of Islam. Shalih bin Fauzan Al-Fauzan, Syarah Nawaaqidhul Islam (Jakarta: Akbar Media, 2017), 122-40.

${ }^{49}$ OHCHR, "Blasphemy Law Has No Place in a Tolerant Nation like Indonesia - UN Rights Experts," Office of the High Commissioner of Human Rights, May 22, 2017, http://www.ohchr.org/EN/NewsEvents/Pages/DisplayNews.aspx?NewsID=21646 \&LangID=E; HRC, “General Comments No. 34 (CCPR/C/GC/34)” (Geneva, 2011), https://www2.ohchr.org/english/bodies/hrc/docs/gc34.pdf.

${ }^{50}$ Imam ibn Al-Mundzir Al-Naysaburi, Al-Ijma (Saudi Arabia: Maktabah Al-Furqan, 1999), 174.
} 
The secular IHRL position sees no virtue in criminalizing religious blasphemy. This is because inter alia most major textbooks explain 'benefit' as a purpose of law with Jeremy Bentham's utilitarianism. ${ }^{51}$ John Stuart Mill, Bentham's student, stated that punishments should only be applied only to prevent material danger or loss towards other members of the society (as opposed to the moral infringement). ${ }^{52}$ Bentham is secular, and Mill accepts Comte's Law of Three Stages. ${ }^{53}$ Surely they do not consider metaphysical danger or loss such as in the context of aqidah. ${ }^{4}$

On the other hand, Islam sees it differently. The purpose of the Syarīah (maqāșid al-syarìah) is to achieve mașlahat (advantage) both in this world and the hereafter. ${ }^{55}$ Mașlahat is therefore divided into the hereafter's mașlahat and the world mașlahat. ${ }^{56}$ The hereafter's mașlahat truly takes precedence over the world mașlahat, 57 because Islam sees this world as a mere means to achieve the hereafter ${ }^{58}$ and heaven is the best destination in that hereafter. ${ }^{59}$

One of the subjects under maslahat is the hifdz al-din (preservation of belief, meaning towards Islam) is the glorification of

51 Sudikno Mertokusumo, Mengenal Hukum: Suatu Pengantar (Yogyakarta: Liberty Press, 2006), 80; Marzuki, Pengantar Ilmu Hukum, 119; Achmad Ali, Menguak Tabir Hukum, 2nd Edition (Jakarta: Penerbit Kencana, 2015), 92-95.

${ }^{52}$ John Gray, Mill on Liberty: A Defence, Second Edition (London and New York: Routledge, 1996), 3.

${ }^{53}$ James E. Crimmins, "Bentham on Religion: Atheism and the Secular Society," Journal of the History of Ideas 47, no. 1 (1986): 95-110; Sujith Shashi Kumar, "Reassessing JS Mill's Liberalism: The Influence of Auguste Comte, Jeremy Bentham, and Wilhelm von Humboldt." (London School of Economics and Political Science (United Kingdom), 2006), 62.

${ }^{54}$ Further discussions regarding utilitarianism and maqāṣid al-syarī ah: Nurizal Ismail, Fajri Matahati Muhammadin, and Hanindito Danusatya, "The Urgency to Incorporate Maqasid Shari'ah as an Eludication of 'Benefit' as a Purpose of Law in Indonesia's Legal Education," in 1st International Conference on Law, Technology, and Society (ICOLESS) 2018 (Malang: Universitas Islam Negeri Maulana Malik Ibrahim, 2019).

${ }^{55}$ Imam Ibn Ashur, Treatise on Maqasid Al-Shariah (London: IIIT, 2006), 71.

${ }^{56}$ Imam Al-Ghazali, Shifa'al-Ghalil Fi Bayan Al-Syabah Wa Al-Mukhil Wa Masalik AlTa'lil (Baghdad: Mathba'ah al-Irsyad, 1971), 159-61.

${ }^{57}$ Al-Ghazali, 159; Nyazee, Islamic Jurisprudence, 204-6.

${ }^{58}$ Imam Ibn Al-Qayyim Al-Jawziyah, 'Uddatush Shabirin (Jakarta: Qisthi Press, 2010), 264.

${ }^{59}$ See inter alia: Q.S Ali Imron 3:185. 
Allah, His din (religion), and his messengers (i.e. prophets). ${ }^{60}$ Blasphemy violates that very fundamental and basic aspect of Islam, ${ }^{61}$ and Muslims committing it are considered no longer in the fold of Islam and therefore the laws related to apostasy (riddah) would apply towards them. ${ }^{62}$

It is therefore clear that IHRL which is based on secular-based jurisprudence and thought cannot accept the criminalization of religious blasphemy, while Islam can. Which epistemology should one choose? This is not a difficult choice for Muslim studying law in a state-based upon the Pancasila as a state ideology. Surely this can be debated further. However, if this difference is not even introduced in the classrooms, students will not be able to objectively and accurately comprehend problems rising from these epistemological differences between IHRL and Islam. Consequently, they will be unable to make proper and coherent conclusions when analyzing those problems.

It is understood that this discussion seems more of a philosophical discussion rather than that of law. However, multidisciplinary approaches in legal education (or the education any field, really) is an inevitability. ${ }^{63}$

\section{The Concept of 'Human Obligations' in Islam}

In the realm of IHRL, the term 'rights' (meaning 'entitlement'), is often mentioned as a recurring theme. On the other hand, the term 'obligation', is rarely mentioned other than 'obligation to respect/guarantee rights'. Islam is different in this respect, and this difference has paradigmatic implications.

IHRL is constructed to heavily lean towards rights, one of the factors is that it historically was a regime born out of the extremely massive violation of human rights during World Wars I and II.64

\footnotetext{
${ }^{60 ` A b d ~ a l-R a h ̣ m a ̄ n ~ A l-S a ' d i, ~ T a y s i r u ~ A l-K a r i ̀ m a ~ A l-R a h ̣ m a ̄ n ~ F i ̀ ~ T a f s i ̀ r i ~ K a l a ̄ m i ~ A l-M a n n a ̄ n ~}$ (Cairo: Dar al-Hadith, 2002), 357.

${ }^{61} \mathrm{Al}-S a ' d i, 357$. See also: Imam Ibn Al-Qayyim Al-Jawziyah, Al-Jawāa Al-Käfi (AlMaghrib: Dar al-Ma'rifah, 1997), 46.

${ }^{62}$ See: Q.S al-Tawbah, 9:65-66. See also: Imam Muhammad bin 'Abd al-Wahhab, Nawaqidhul Islam - Pembatal Islam (Matan dan Terjemah) (Surabaya: Pustaka Syabab, 2015), 164-83.

${ }^{63}$ See: Mochtar Kusumaatmadja, "Pendidikan Hukum di Indonesia: Penjelasan Tentang Kurikulum 1993," Jurnal Hukum \& Pembangunan 6, no. 1994 (1994): 498-99.

${ }^{64}$ Shaw, International Law, 271.
} 
However, this absence of 'human obligations' to balance the 'human rights' was one of the main critics of the Indonesian Council of Ulema towards international human rights. 65 This problem is also a deviation from the pattern of balance between rights and obligations in legal education. For example, law students are taught in their first semester about the relation between 'law, rights, and obligations' ${ }^{66}$ Even, Law No. 39 of 1999 concerning Human Rights prescribes Kewajiban Dasar Manusia (i.e. human fundamental obligations). ${ }^{67}$

If two different regimes have different constructions of balancing rights and obligations, surely there would be very different understandings of what 'rights' mean and how they are perceived. As a consequence, the detailed enumeration of rights would surely have different meanings between the two different regimes altogether. This is the case with IHRL and Islam.

Islam, in contrast to IHRL, provides both rights and obligations while somewhat inclining towards obligations. From the most fundamental nature of a human being, humans are created with the obligation -not rights-to worship Allah as explained in Q.S alDzāriyāt 51:56: "And I did not create the genie and mankind except to worship Me."

Only then that Allah decrees that humans have rights as $\mathrm{He}$ is Al-Rahmān which means The Most Compassionate and Merciful towards all creation without exception ${ }^{68}$ and has prohibited $d z u l m$ (the violation of rights) upon Himself and all creation. ${ }^{69}$ This is why, as argued by Shamrahayu bt. Abdul Aziz, Islam is essentially duty-

\footnotetext{
${ }^{65 “}$ Fatwa Majelis Ulama Indonesia No. 6/MUNAS VI/MUI/2000 Tentang Hak Asasi Manusia" (Jakarta, 2000), 381, https://mui.or.id/wp-content/uploads/2017/02/26.Hak-hak-Asasi-Manusia-HAM.pdf.

${ }^{66}$ Mertokusumo, Mengenal Hukum (Suatu Pengantar), 38-46.

${ }^{67}$ Articles 67-70 of Law No. 39. Of 1999 concerning Human Rights: Obeying the law, defending the state, and respecting the human rights of other people.

${ }^{68}$ Imam Ismail ibn Katsir, Tafsir Al-Qur'an Al-Adzim, vol. 1 (Beirut: Dar al-Kutub 'Ilmiya, 1998), 39.

${ }^{69}$ Imam Muslim, Sahih Muslim (Riyadh: Bait Al-Afkar Ad-Dauliyyah, 1998), hadīts no.2577. Imam An-Nawawi and Muhammad bin Shalih Al-Utsaimin, Syarah Hadits Arba'in Imam Nawawi (Yogyakarta: Media Hidayah, 2006), 195.
} 
based.70 This difference with IHRL would create paradigmatic differences towards derivative issues which, if not understood, would result in misunderstanding.

\section{A Case Study on Derivative Issues}

Among the differences between IHRL and Islam due to the difference in the construction of rights and obligations is related to knowledge and education. IHRL, through Article 13 (1) of the International Covenant on Economic, Social, and Cultural Rights 1966 (ICESCR), prescribes a right to education.

On the other hand, to receive an education is not a right but rather an obligation. ${ }^{71}$ Islamic jurists divide knowledge in two types: first, knowledge which is obligatory to be learned by everyone (fard al-'ayn) such as the knowledge of tawhì and basic figh;72 and second, knowledge which is obligatory to some people (fard al-kifāyah) due to a collective necessity of it within the community, such as medical science. ${ }^{73}$

The Islamic State has obligations to inter alia implement and enforces the Syari'ah (which contains rights and obligations), ${ }^{74}$ which includes providing education to facilitate the society's need to fulfil their obligation to receive an education. This would also mean that the society would then also have rights to be guaranteed to receive education by the Islamic State so that they can fulfill their obligation as explained earlier. From here, more derivative issues may follow, such as whether someone may choose to be uneducated (IHRL: yes, Islam: no), and many more.

A second derivative issue that resulted from the different construction in rights and obligations, which is very central, is the issue of religion and worship. On one hand, the ICCPR in articles

\footnotetext{
${ }^{70}$ Shamrahayu Binti Abdul Aziz, "Islamic Concept of Human Rights," in Human Rights Law: International, Malaysian and Islamic Perspectives, ed. Abdul Ghafur Hamid @ Khin Maung Sein (Selangor: Thomson Reuters Malaysia Sdn Bhd, 2012), 329.

${ }^{71}$ See inter alia: QS. Taha 20: 114, QS. Al-Nahl 16: 78, QS. Muhammad 47: 19, and see also: Imām Al-Ghazāli, Iḥyā' 'Ulūm Al-Dìn, vol. 1 (Beirut: Dar al-Kutub 'Ilmiya, 1971), 14.

${ }^{72}$ Al-Ghazāli, 1:14.

${ }^{73}$ Al-Ghazāli, 1:15-16.

${ }^{74}$ Musthafa Al-Khin and Musthafa Al-Bugha, Konsep Kepemimpinan dan Jihad dalam Islam: Menurut Madzhab Syafi'i (Jakarta: Darul Haq, 2014), 110-11.
} 
18(1)-(2) rules that every human being has the freedom to choose their religion and manifest them in acts of worship, and that they may not be forced in a manner that would disrupt that freedom. Here, the role of the government is to guarantee that such freedom is enjoyed by their people.

Islam sees the issue very differently. As explained earlier, to worship Allah is essentially an obligation (instead of a right) towards all jinn and human beings as Q.S al-Dzāriyāt 51:56 mentions. Besides, Islam only recognizes one religion (i.e. Islam) as the true religion as Q.S Ali Imrān 3:19 stated: "Indeed, the religion in the sight of Allah is Islam."

As a side note, it is important to note that the consequence of the obligation to worship Allah in Islamic terms does not mean that Muslims may coerce non-Muslims to accept Islam. ${ }^{75}$ Rather, it is understood to mean that Muslims must conduct $d a^{\prime} w a h$ (propagation) with good arguments and in the best of manners. ${ }^{76}$ If a non-Muslim refuses to accept Islam until the end of her/his life, it would be their business with Allah. ${ }^{77}$

The differences of construction between IHRL and Islam regarding religion and worship, which is a right according to IHRL and an obligation according to Islam, causes a complex relationship between the two. At times, IHRL and Islam can agree on certain issues. For example, the Human Rights Committee declared that the hijāb (or khimār, referring to the headscarf worn by Muslim women) prohibition in Uzbekistan was a violation of human rights. ${ }^{78}$ The Muslims would surely support the condemnation towards that Uzbekistan policy. However, there are times when disagreements and misunderstandings occur between IHRL and Islam. An example of

\footnotetext{
${ }^{75}$ See: QS. Al-Baqarah 2: 256, and: Haji Abdulmalik Abdulkarim Amrullah, Tafsir AlAzhar, vol. 1 (Singapore: Pustaka Nasional PTE Ltd, n.d.), 623-24.

${ }^{76}$ Haji Abdulmalik Abdulkarim Amrullah, Tafsir Al-Azhar, vol. 5 (Singapore: Pustaka Nasional PTE Ltd, n.d.), 3989-90.

${ }^{77}$ I.e. to receive punishment in the hereafter. See: QS. Al-Kahf 18:29, also see: Haji Abdulmalik Abdulkarim Amrullah, Tafsir Al-Azhar, vol. 6 (Singapore: Pustaka Nasional PTE Ltd, n.d.), 4191.

78 UN Human Rights Committee, Hudoyberganova v. Uzbekistan, CCPR/C/82/D/931/2000, para. 6.2.
} 
this is Ann Elizabeth Mayer's critic of the imposition of hijāb in Saudi Arabia. ${ }^{79}$

According to Mayer, Saudi's policy is not Islamic teaching but rather a mere political maneuver. In her explanation, it is clear that Mayer sees that for Muslim women to wear the hijāb is a right (which may or may not be exercised, at the discretion of the individuals), while the government should have only taken the role as guarantor of rights. ${ }^{80}$ However, in Islam, wearing a hijāb is obligatory for grown-up women. ${ }^{81}$ As explained earlier, an Islamic state has to implement and enforce the Syari'ah which is duty-based. This is different from an IHRL construct, where Mayer seems to misunderstand and therefore ends up with an inaccurate conclusion.

\section{Conclusion}

It has also been shown that there are some paradigmatic differences between IHRL and the Islamic concept of rights which, if not understood, will cause much misunderstanding. It is difficult to truly understand religion-related issues such as deviant sects or religious blasphemy if one analyzes the relevant Islamic laws but using a secular epistemology. For instance, failing to understand the difference in the construction of rights and obligations (i.e. IHRL focusing on rights, and Islam focusing on both but leaning towards obligations) would also lead to misunderstanding and confusion in derivative issues. Therefore, it is essential to incorporate the Islamic concept of rights in the curriculum of the IHRL course in Indonesian law schools. More importantly, the syllabus must emphasize the identification and understanding of the paradigmatic differences between IHRL and the Islamic concept of rights. This is hoped to help facilitate the students to be able to study and analyze issues related to IHRL and Islam more objectively and accurately.

\section{Bibliography}

'Abd al-Wahhab, Imam Muhammad bin. Nawaqidhul Islam - Pembatal

\footnotetext{
${ }^{79}$ Mayer, “Universal versus Islamic Human Rights: A Clash of Cultures or Clash with a Construct," 393-97.

${ }^{80}$ Mayer, 402-3.

${ }^{81}$ Except in front of their immediate family. Imam ibn Ḥazm, Marātib Al-Ijmā' (Beirut: Dar al-Kutub al-'Ilmiyyah, n.d.).
} 
Islam (Matan Dan Terjemah). Surabaya: Pustaka Syabab, 2015.

Acac, Marybeth T. "Pancasila: A Contemporary Application of Maqasid Al-Shari' Ah?" Journal of Indonesian Islam 9, no. 1 (2015): 59-78.

Al-Attas, Syed Muhammad Naquib. Islam and Secularism. Kuala Lumpur: ISTAC, 1993.

- - - Risalah Untuk Kaum Muslimin. Kuala Lumpur: ISTAC, 2001.

Al-Awadhi, Badria. "Address by the Dean of the Faculty of Law and Shari'a in the University of Kuwait." In Human Rights in Islam. Geneva: International Commission of Jurists, 1982.

Al-Fauzan, Shalih bin Fauzan. Syarah Nawaaqidhul Islam. Jakarta: Akbar Media, 2017.

Al-Ghazali, Imam. Shifa'al-Ghalil Fi Bayan Al-Syabah Wa Al-Mukhil Wa Masalik Al-Ta'lil. Baghdad: Mathba'ah al-Irsyad, 1971.

Al-Ghazāli, Imām. Iḥyā' 'Ulūm Al-Dìn. Vol. 1. Beirut: Dar al-Kutub 'Ilmiya, 1971.

Al-Jawziyah, Imam Ibn Al-Qayyim. 'Uddatush Shabirin. Jakarta: Qisthi Press, 2010.

- - - Al-Jawā̄b Al-Kāfí. Al-Maghrib: Dar al-Ma'rifah, 1997.

Al-Khasawneh, Awn S. "Islam and International Law." In Islam and International Law: Engaging Self-Centrism from a Plurality of Perspectives, edited by Marie-Luisa Frick and Andreas Th Müller, 29-44. Martinus Nijhoff Publishers, 2013.

Al-Khin, Musthafa, and Musthafa Al-Bugha. Konsep Kepemimpinan Dan Jihad Dalam Islam: Menurut Madzhab Syafi'i. Jakarta: Darul Haq, 2014.

Al-Naysaburi, Imam ibn Al-Mundzir. Al-Ijma. Saudi Arabia: Maktabah Al-Furqan, 1999.

Al-Sa'di, 'Abd al-Raḥmān. Taysiru Al-Karìma Al-Raḥmān Fì Tafsìri Kalāmi Al-Mannān. Cairo: Dar al-Hadith, 2002.

Al-Shaybānī, Imam. The Islamic Law of Nations: Shaybani's Siyar. Translated by Majid Khadduri. Maryland: John Hopkins Press, 1966.

Al-Taftazani, Sa'd al-Din. A Commentary on the Creed of Islam ( $\mathrm{Sa}^{\prime} \mathrm{d} \mathrm{Al}$ Din Al-Taftazani on the Creed of Najm Al-Din Al-Nasafi). New York: Columbia University Press, 1950.

al-Zuhaylī, Wahbah. Ușūl Al-Fiqh Al-Islāmī. Vol. 1. Tehran: Dar Ihsan, 1997. 
Ali, Achmad. Menguak Tabir Hukum. 2nd Editio. Jakarta: Penerbit Kencana, 2015.

Amrullah, Haji Abdulmalik Abdulkarim. Tafsir Al-Azhar. Vol. 1. Singapore: Pustaka Nasional PTE Ltd, n.d.

- - - Tafsir Al-Azhar. Vol. 5. Singapore: Pustaka Nasional PTE Ltd, n.d.

- - - Tafsir Al-Azhar. Vol. 6. Singapore: Pustaka Nasional PTE Ltd, n.d.

An-Na'im, Abdullahi Ahmed. "Why Should Muslims Abandon Jihad? Human Rights and the Future of International Law." Third World Quarterly 27, no. 5 (2006): 785-97.

An-Nawawi, Imam, and Muhammad bin Shalih Al-Utsaimin. Syarah Hadits Arba'in Imam Nawawi. Yogyakarta: Media Hidayah, 2006.

Anghie, Antony. Imperialism, Sovereignty, and the Making of International Law. New York: Cambridge University Press, 2004.

- - - "Towards a Postcolonial International Law." In Critical International Law: Post-Realism, Post Colonialism, and Transnationalism, edited by Prabakhar Singh and Benoit Mayer, 121-42. Oxford-New Dheli, 2014.

Armas, Adnin, and Dinar Dewi Kania. "Sekulerisasi Ilmu." In Filsafat Ilmu: Perspektif Barat Dan Islam, edited by Adian Husaini and Dinar Dewi Kania. Jakarta: Gema Insani Press, 2013.

Ashur, Imam Ibn. Treatise on Maqasid Al-Shariah. London: IIIT, 2006.

Austin, John. The Province of Jurisprudence Determined. London: John Murray, 1832.

Aziz, Shamrahayu binti Abdul. "Islamic Concept of Human Rights." In Human Rights Law: International, Malaysian and Islamic Perspectives, edited by Abdul Ghafur Hamid @ Khin Maung Sein. Selangor: Thomson Reuters Malaysia Sdn Bhd, 2012.

Baderin, Mashood A. Hukum Internasional Hak Asasi Manusia Dan Hukum Islam. Jakarta: Komisi Nasional Hak Asasi Manusia, 2010.

Baderin, Mashood A. International Human Rights and Islamic Law. Oxford: Oxford University Press, 2003.

Bartels, Lorand. "The European Parliament's Role in Relation to Human Rights in Trade and Investment Agreements," 2014. http:// www.europarl.europa.eu/cmsdata/86031/Study.pdf.

Comte, Auguste. "Plan of the Scientific Work Necessary for the Reorganisation o f Society." In Comte: Early Political Writings, 
edited by H.S. Jones. Cambridge: Cambridge University Press, 1998.

Cox, Harvey. The Secular City: Secularization and Urbanization in Theological Perspective. New Jersey: Princeton University Press, 2013.

Crimmins, James E. "Bentham on Religion: Atheism and the Secular Society." Journal of the History of Ideas 47, no. 1 (1986): 95-110.

Daud, Wan Mohd Nor Wan. Islamization of Contemporary Knowledge and the Role of the University in the Context of De-Westernization and Decolonialization. Johor Baru: UTM Press, 2013.

Desilver, Drew, and David Masci. “World's Muslim Population More Widespread than You Might Think." Pew Research Center, 2017. http://www.pewresearch.org/fact-tank/2017/01/31/worldsmuslim-population-more-widespread-than-you-might-think/.

Farrar, Salim. "The Organisation of Islamic Cooperation: Forever on the Periphery of Public International Law?" Chinese Journal of International Law 13, no. 4 (2014): 787-817.

"Fatwa Majelis Ulama Indonesia No. 6/MUNAS VI/MUI/2000 Tentang Hak Asasi Manusia." Jakarta, 2000. https:/ / mui.or.id/wp-content/ uploads/2017/02/26.-Hak-hakAsasi-Manusia-HAM.pdf.

Freeman, Michael. "The Problem of Secularism in Human Rights Theory." Human Rights Quarterly 26, no. 2 (2004): 375-400.

Gray, John. Mill on Liberty: A Defence. Second Edi. London and New York: Routledge, 1996.

Harnack, Justus. Kant's Theory of Knowledge. London: Macmillan Publisher, 1968.

HRC. "General Comments No. 34 (CCPR/C/GC/34)." Geneva, 2011. https://www2.ohchr.org/english/bodies/hrc/docs/gc34.pdf.

Husaini, Adian, and Dinar Dewi Kania, eds. Filsafat Ilmu: Perspektif Barat Dan Islam. Jakarta: Gema Insani Press, 2013.

ibn Hazm, Imam. Marātib Al-Ijmā’. Beirut: Dar al-Kutub al-`Ilmiyyah, n.d.

ibn Katsir, Imam Ismail. Tafsir Al-Qur'an Al-Adzim. Vol. 1. Beirut: Dar al-Kutub 'Ilmiya, 1998.

Ismail, Nurizal, Fajri Matahati Muhammadin, and Hanindito Danusatya. "The Urgency to Incorporate Maqasid Shari'ah as an Eludication of 'Benefit' as a Purpose of Law in Indonesia's Legal 
Education." In 1st International Conference on Law, Technology, and Society (ICOLESS) 2018. Malang: Universitas Islam Negeri Maulana Malik Ibrahim, 2019.

Istanto, Sugeng. Hukum Internasional. Yogyakarta: Penerbit Universitas Atmajaya Yogyakarta, 1994.

Khan, Zara. "Refractions Through the Secular: Islam, Human Rights, and Universality." The City University of New York, 2016.

Kimberly, Vina Berliana, Novita Dwi Lestari, and Fajri Matahati Muhammadin. "Incorporating Qawaidh Fiqhiyyah to the 'Principles of Law' Chapter in the Introduction to Jurisprudence Course in Indonesia's Legal Education." In International Conference on Research in Islamic Education 2018 Conference Proceeding, Fakulti Tamadun Islam, Universiti Teknologi Malaysia, (upcoming). Kuala Lumpur: Springer, 2019.

Kumar, Sujith Shashi. “Reassessing JS Mill's Liberalism: The Influence of Auguste Comte, Jeremy Bentham, and Wilhelm von Humboldt." London School of Economics and Political Science (United Kingdom), 2006.

Kusumaatmadja, Mochtar. "Pendidikan Hukum Di Indonesia: Penjelasan Tentang Kurikulum 1993." Jurnal Hukum E Pembangunan 6, no. 1994 (1994): 491-501.

Lane, Edward William. An Arabic-English Lexicon: In Eight Parts. Vol. 3. Beirut: Librairie du Liban, 1968.

Marzuki, Peter Mahmud. Pengantar Ilmu Hukum. Jakarta: Prenadamedia Group, 2008.

Mayer, Ann Elizabeth. "Universal versus Islamic Human Rights: A Clash of Cultures or Clash with a Construct." Mich. J. Int'l L. 15 (1993): 307.

Mertokusumo, Sudikno. Mengenal Hukum: Suatu Pengantar. Yogyakarta: Liberty Press, 2006.

- - - Mengenal Hukum (Suatu Pengantar). 3rd ed. Yogyakarta: Liberty, 1991.

Muhammadin, Fajri Matahati. "Universalitas Hak Asasi Manusia Dalam Hukum Internasional: Sebuah Pendekatan PostKolonial." In Hak Asasi Manusia: Dialektika Universalisme vs Relativisme Di Indonesia, edited by Al-Khanif, Herlambang P. Wiratraman, and Manunggal Kusuma Wardaya, 1-20. Yogyakarta: LKiS, 2017. 
Muhammadin, Fajri Matahati, and Hanindito Danusatya. "DeSecularizing Legal Education in Indonesian Non-Islamic Law Schools: Examining The 'Introduction to Jurisprudence' Textbooks On The 'Norm Classification' Chapter." Ulul Albab: Jurnal Studi Dan Penelitian Hukum Islam 1, no. 2 (2018): 135-58.

Muhammadin, Fajri Matahati, Dian Agung Wicaksono, Almonika Cindy Fatika Sari, and Ola Anisa Ayutama. "Lashing in Qanun Aceh and the Convention Against Torture." Malaysian Journal of Syariah and Law 7, no. 1 (2019): 11-24.

Muslim, Imam. Sahih Muslim. Riyadh: Bait Al-Afkar Ad-Dauliyyah, 1998.

Nyazee, Imran Ahsan Khan. Islamic Jurisprudence. Selangor: The Other Press, 2003.

OHCHR. "Blasphemy Law Has No Place in a Tolerant Nation like Indonesia - UN Rights Experts." Office of the High Commissioner of Human Rights. May 22, 2017. http://www.ohchr.org/EN/NewsEvents/Pages/DisplayNews. aspx?NewsID=21646\&LangID $=\mathrm{E}$.

Pictet, Jean. Development and Principles of International Humanitarian Law. Geneva: Henry Dunant Institute, 1985.

Quane, Helen. "Legal Pluralism and International Human Rights Law: Inherently Incompatible, Mutually Reinforcing or Something in Between?" Oxford Journal of Legal Studies 33, no. 4 (2013): 675-702.

Rahardjo, Satjipto. Ilmu Hukum. Bandung: Citra Aditya Bhakti, 1991.

Ramlah. "Implikasi Pengaruh Politik Hukum Kolonial Belanda Terhadap Badan Peradilan Agama Di Indonesia." Jurnal Kajian Hukum Islam 12, no. 1 (2012): 387-406.

Rohman, M. Saifullah. "Kandungan Nilai-Nilai Syariat Islam Dalam Pancasila." Jurnal Studi Agama Millah 13, no. 1 (2013): 205-15.

Samour, Nahed. "Is There a Role for Islamic International Law in the History of International Law?" European Journal of International Law 25, no. 1 (2014): 313-19.

Shaw, Malcolm N. International Law. 6th ed. New York: Cambridge University Press, 2008.

Vattel, Emer De, and Joseph Chitty. The Law of Nations: Or, Principles of the Law of Nature, Applied to the Conduct and Affairs of Nations and Sovereigns. PH Nicklin \& T. Johnson, 1835. 
Sigit Riyanto, Fajri Matahati Muhammadin

Zaydan, 'Abd al-Karim. Synopsis on the Elucidation of Legal Maxims in Islamic Law. Translated by Md. Habibur Rahman and Azman Ismail. Kuala Lumpur: IBFIM, 2015. 